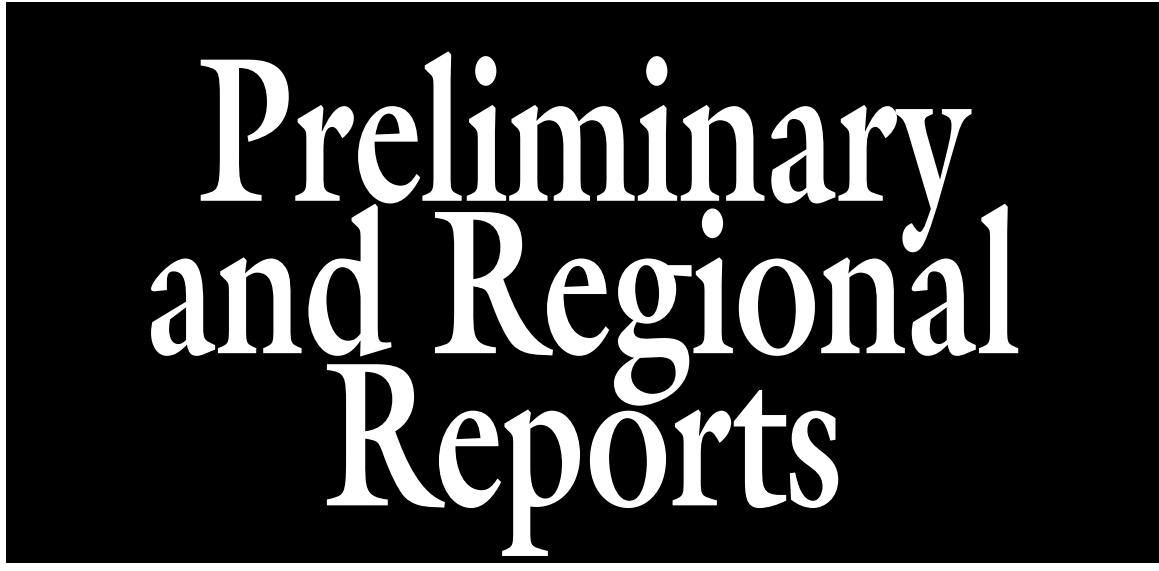

\section{Effect of Organic Fertilizer Source and Rate on Growth and Nutrient Leachate Profile of Greenhouse-grown Cucumber}

\author{
Yuqi $\mathrm{Li}^{1}$ and Neil S. Mattson ${ }^{2,3}$
}

AdDITIONAL INDEX WORDs. compost, Cucumis sativus, nutrient leaching, substrate, vermicompost

SUMMARY. Fertility management of seedlings and transplants is considered a key challenge in organic greenhouse production. This study was conducted to determine response of greenhouse-grown cucumber (Cucumis sativus) and nutrient release profile to two organic fertilizers and their combinations applied at three different concentrations in organic substrate. The organic fertilizers used were a turkey litter-based compost (TC) and a dairy manure vermicompost (VC). In addition, two control treatments [no fertilization (CK), conventional liquid fertilizer (CF)] were included. For TC, substrate leachate $\mathrm{pH}$ decreased for the first 17 days after addition and then increased, whereas electrical conductivity (EC), and calcium $(\mathrm{Ca})$ and nitrate-nitrogen $\left(\mathrm{NO}_{3}{ }^{-}-\mathrm{N}\right)$ concentrations increased and then declined. For VC, EC decreased continuously over time from days 0 to 52, whereas $\mathrm{pH}$ increased. The $\mathrm{Ca}$ and $\mathrm{NO}_{3}{ }^{-}-\mathrm{N}$ concentrations decreased over time to 24 days and then did not change further. For TC/VC combinations, EC was stable for the first 17 days and then declined. For all organic fertilizer applications, potassium concentration was stable for the first 17 days and then decreased, whereas most of the sodium, ammonium-nitrogen, and chloride were no longer leached by 24 days. The VC and TC/VC combinations did not affect cucumber seed germination rate, seedling survival rate, seedling height, and leaf greenness (SPAD) as compared with CF. The stem length, leaf number, dry weight (DW), root index, and SPAD readings of cucumber transplants increased with increasing TC and VC fertilizer applications. The TC/VC combinations increased the biomass of cucumber transplants compared with CK, and did not differ from CF. The results of this study indicated that the $28.32 \mathrm{lb} / \mathrm{yard}^{3}$ of VC (high rate) or the $9.44 \mathrm{lb} / \mathrm{yard}^{3}$ of VC combined with $4 \mathrm{lb} / \mathrm{yard}^{3}$ of TC (medium rate) can be substituted for CF for the cultivation of cucumber seedlings. Based on DW, the $12 \mathrm{lb} /$ yard $^{3}$ of TC (high rate) or the $4 \mathrm{lb} /$ yard $^{3}$ of TC combined with $9.44 \mathrm{lb} /$ yard $^{3}$ of VC (medium rate) fertilizers were suitable replacements for $\mathrm{CF}$ for the cultivation of cucumber transplants.

$\mathrm{T}$ increase in consumer demand for fresh organic fruits and vegetables has been recognized by many greenhouse producers throughout the world, including China and the United States (Burnett et al., 2016; Meng et al., 2017; Olczyk et al., 2007; Treadwell et al., 2007). Among organic greenhouse relationship to plant growth (Bi et al., 2010; Burnett et al., 2016). In addition, the feedstocks and methods for producing organic fertilizers are extremely variable, which results in different components and physiochemical properties among different organic fertilizers. Many traditional organic fertilizers are produced as composts or other formulated byproducts of livestock, fish, and food and other processing industries, including feather meal, blood meal, meat and bone meal, and manure-based materials (Bi et al., 2010; Gaskell and Smith, 2007).

Vermicomposts, produced using the fragmentation of organic wastes by earthworms, have a fine particulate structure and contain nutrients in forms that are more readily taken up by the plants, such as $\mathrm{NO}_{3}^{-}-\mathrm{N}$, available phosphorus, potassium $(\mathrm{K}), \mathrm{Ca}$, and magnesium (Arancon et al., 2006; Atiyeh et al., 2000; Brace, 2017; Yang et al., 2015). Arancon et al. (2006) reported that food waste and paper waste vermicomposts can increase the amount of ammoniumnitrogen $\left(\mathrm{NH}_{4}-\mathrm{N}\right), \mathrm{NO}_{3}-\mathrm{N}$, and orthophosphates in soil on the harvest date. Vermicompost amendment has been shown to increase the growth, yield, or quality of some greenhouse crops, such as tomato (Solanum lycopersicum), pepper (Capsicum annuum), and cucumber (Arancon et al., 2004; Atiyeh et al., 2000; Zhao et al., 2010). Atiyeh et al. (2000) reported that incorporation of $10 \%$ or $20 \%$ pig solid vermicomposts into a standard commercial horticultural potting substrate (Metro-Mix 360; Sun Gro Horticulture, Agawam, MA) increased the growth of marigold $(\mathrm{Ca}$ lendula officinalis) and tomato seedlings as compared with the standard commercial horticultural potting substrate alone, even when all required mineral nutrients were supplied.

Composting is generally defined as the biological aerobic transformation of an organic byproduct into a different organic product that can be added to the soil without detrimental effects on crop growth (Atiyeh et al., 2000; Baca et al., 1992). The application of composted manure is a common practice in organic culture (Hartz and Johnstone, 2006). Hartz and Johnstone (2006) reported on the effect of temperature on nitrogen $(\mathrm{N})$ availability from feather meal, seabird guano, fish powder, and blood meal in soil. For blood 
meal after 1 week, $18 \%$ of $\mathrm{N}$ had mineralized at $10{ }^{\circ} \mathrm{C}$, and $51 \%$ had mineralized at $25^{\circ} \mathrm{C}$. By 2 weeks, across materials, approximately half or more of all $\mathrm{N}$ had mineralized at $25^{\circ} \mathrm{C}$. Burnett et al. (2016) suggests that substrate-incorporated organic fertilizers are typically used as the sole fertilizer source only for short-term crops because a large proportion of organic nutrients are mineralized within the first few weeks and can leach out of container mixes. Therefore, a difficulty with using organic fertilizers is matching the rate of nutrient release to the plant's nutrient demands (Burnett et al., 2016; Treadwell et al., 2007).

Cucumber is an important greenhouse vegetable crop and one of the most popular members of the cucurbit (Cucurbitaceae) family (Alsadon et al., 2016). In 2017, world production of cucumbers and gherkins was 84 million tonnes, led by China with $77 \%$ of the total (Food and Agriculture Organization of the United Nations, 2019). The objective of this study was to evaluate the effects of organic fertilizer source and rate of application on nutrient leaching over time and to determine the growth response of greenhouse-grown cucumber to two different organic fertilizers.

\section{Materials and methods}

Experimental Design. The substrate used in this experiment was a commercially available organic peat/perlite substrate (Sunshine \#4 Natural and Organic; Sun Gro Horticulture). The plant material consisted of 'Salad Bush Fl' cucumber (Harris Seeds, Rochester, NY). The experiment was performed in a controlled greenhouse at Cornell University, Ithaca, NY (lat. $42^{\circ} \mathrm{N}$ ). Two commercial organic fertilizers were

$\overline{\text { Received for publication } 31 \text { Jan. 2019. Accepted for }}$ publication 19 Apr. 2019.

Published online 20 June 2019.

Use of trade names does not imply an endorsement of the products named or criticism of similar ones not named.

${ }^{1}$ School of Chemical Engineering and Food Sciences, Hubei University of Arts and Science, Xiangyang, Hubei 441053, China

${ }^{2}$ Horticulture Section, School of Integrative Plant Science, Cornell University, Ithaca, NY 14853

${ }^{3}$ Corresponding author. E-mail: nsm47@cornell.edu.

This is an open access article distributed under the CC BY-NC-ND license (https://creativecommons.org/ licenses/by-nc-nd/4.0/).

https://doi.org/10.21273/HORTTECH04293-19 selected: 1) TC $8 \mathrm{~N}-1.8 \mathrm{P}-3.3 \mathrm{~K}$ (Suståne Natural Fertilizer; Cannon Falls, $\mathrm{MN}$ ), and 2) VC $3.4 \mathrm{~N}-1.5 \mathrm{P}-3.1 \mathrm{~K}$ (Worm Power, Avon, NY). Nine organic fertilizer treatments (11 pots per treatment) were designed with three different fertilizers [TC, VC, and the combinations of TC and VC (1:1 $\mathrm{N}$ by weight)] and three $\mathrm{N}$ application levels $[0.32$ (low), 0.64 (medium), and 0.96 (high) lb/yard ${ }^{3}$ ] of each fertilizer. Namely, TC was actually applied at three rates of 4,8 , and $12 \mathrm{lb} /$ yard $^{3}$. The $\mathrm{VC}$ was actually applied at three rates of $9.44,18.88$, and $28.32 \mathrm{lb} / \mathrm{yard}^{3}$. The TC/VC combination was actually applied at three rates of $2 / 4.72,4 / 9.44$, and $6 / 14.16 \mathrm{lb} / \mathrm{yard}^{3}$. In addition, two control treatments [no fertilization (CK), CF $150 \mathrm{mg} \cdot \mathrm{L}^{-1} \mathrm{~N}$ from $21 \mathrm{~N}-$ 2.2P-16.6K (Jack's Professional LX 21-5-20 All Purpose Water-Soluble Fertilizer; J.R. Peters, Allentown, PA)] were included. The organic fertilizers were completely incorporated into the substrate before seeding. One seed of cucumber was sown into each 6-inch-diameter round pot (1.7 L volume) containing the aforementioned substrates ( $\approx$ l inch deep). After $52 \mathrm{~d}$, the cucumber seedlings without root rot from each treatment were transplanted into $10-\mathrm{L}$ pots, again containing the 11 aforementioned substrates. All pots were arranged in a completely randomized design on raised benches. Pots were watered as needed according to treatment with either clear water (CK and organic fertilizer treatments) or in the case of the CF treatment fertigated on weekdays and clear water on weekends. All treatments were watered until substrate reached saturation (i.e., until a small fraction of water leached from the bottom of the pot). During the experimental period, greenhouse temperature was set to a constant $19^{\circ} \mathrm{C}$, and plants were grown under natural lighting from 28 Oct. 2012 to 18 Jan. 2013.
Data collection. During the experimental period, substrate leachate was collected weekly using the nondestructive PourThru extraction method (Wright, 1986). Substrate leachate $\mathrm{pH}$ was measured using a pH meter (pHTestr 20; Oakton Instruments, Vernon Hills, IL), and EC using an EC meter (ECTestr 11, Oakton Instruments). During the seedling stage, element concentration in substrate leachate $\left[\mathrm{Ca}, \mathrm{NO}_{3}{ }^{-} \mathrm{N}, \mathrm{K}\right.$, sodium $(\mathrm{Na}), \mathrm{NH}_{4}{ }^{+}-\mathrm{N}$, and chloride $(\mathrm{Cl})$ ] was measured using a multi-ion meter (CG001; CleanGrow, Vacaville, CA). The meter was calibrated before use and after every 10 samples. At the end of seedling stage, plant heights, leaf number, and SPAD were measured. At the end of posttransplanted stage, stem length (from soil to the apical meristem), fresh weight (FW), DW, root index (RI), and SPAD readings were measured. The SPAD readings were quantified using a nondestructive dual-wavelength chlorophyll meter (Minolta SPAD-502 chlorophyll meter; Spectrum Technologies, Plainfield, IL) and the average reading of three recently mature leaves per plant was taken. At harvest, the plant stem was cut at the soil line and shoot FW was recorded. Shoots were then oven dried at $70{ }^{\circ} \mathrm{C}$ for $72 \mathrm{~h}$ to determine shoot DW. The RI was evaluated using a 0 to 5 scale according to visible root density at the substrate surfaces, with 0 indicating no visible roots at the substrate/container wall interface and 5 indicating visible roots were matted on the substrate/container wall interface (Bi et al., 2009; Li and Mattson, 2016). For each treatment, four replicates were carried out.

Statistical analysis. Analysis of variance was conducted using the general linear model program of SAS (version 9.3; SAS Institute, Cary, NC). Means were separated using the least significant difference test at $P<0.05$.

\begin{tabular}{llll}
\hline $\begin{array}{l}\text { Units } \\
\text { To convert U.S. to SI, } \\
\text { multiply by }\end{array}$ & U.S. unit & SI unit & $\begin{array}{l}\text { To convert SI to U.S., } \\
\text { multiply by }\end{array}$ \\
\hline 3.7854 & gal & $\mathrm{L}$ & 0.2642 \\
2.54 & inch $(\mathrm{es})$ & $\mathrm{cm}$ & 0.3937 \\
0.5933 & $\mathrm{lb} / \mathrm{yard}$ & $\mathrm{kg} \cdot \mathrm{m}^{-3}$ & 1.6856 \\
1 & $\mathrm{mmho} / \mathrm{cm}$ & $\mathrm{mS} \cdot \mathrm{cm}^{-1}$ & 1 \\
28.3495 & $\mathrm{oz}$ & $\mathrm{g}$ & 0.0353 \\
1 & $\mathrm{ppm}$ & $\mathrm{mg} \cdot \mathrm{L}^{-1}$ & 1 \\
0.9072 & ton $(\mathrm{s})$ & tonne $(\mathrm{s})$ & 1.1023 \\
$\left({ }^{\circ} \mathrm{F}-32\right) \div 1.8$ & ${ }^{\circ} \mathrm{F}$ & ${ }^{\circ} \mathrm{C}$ & $\left({ }^{\circ} \mathrm{C} \times 1.8\right)+32$ \\
& & &
\end{tabular}




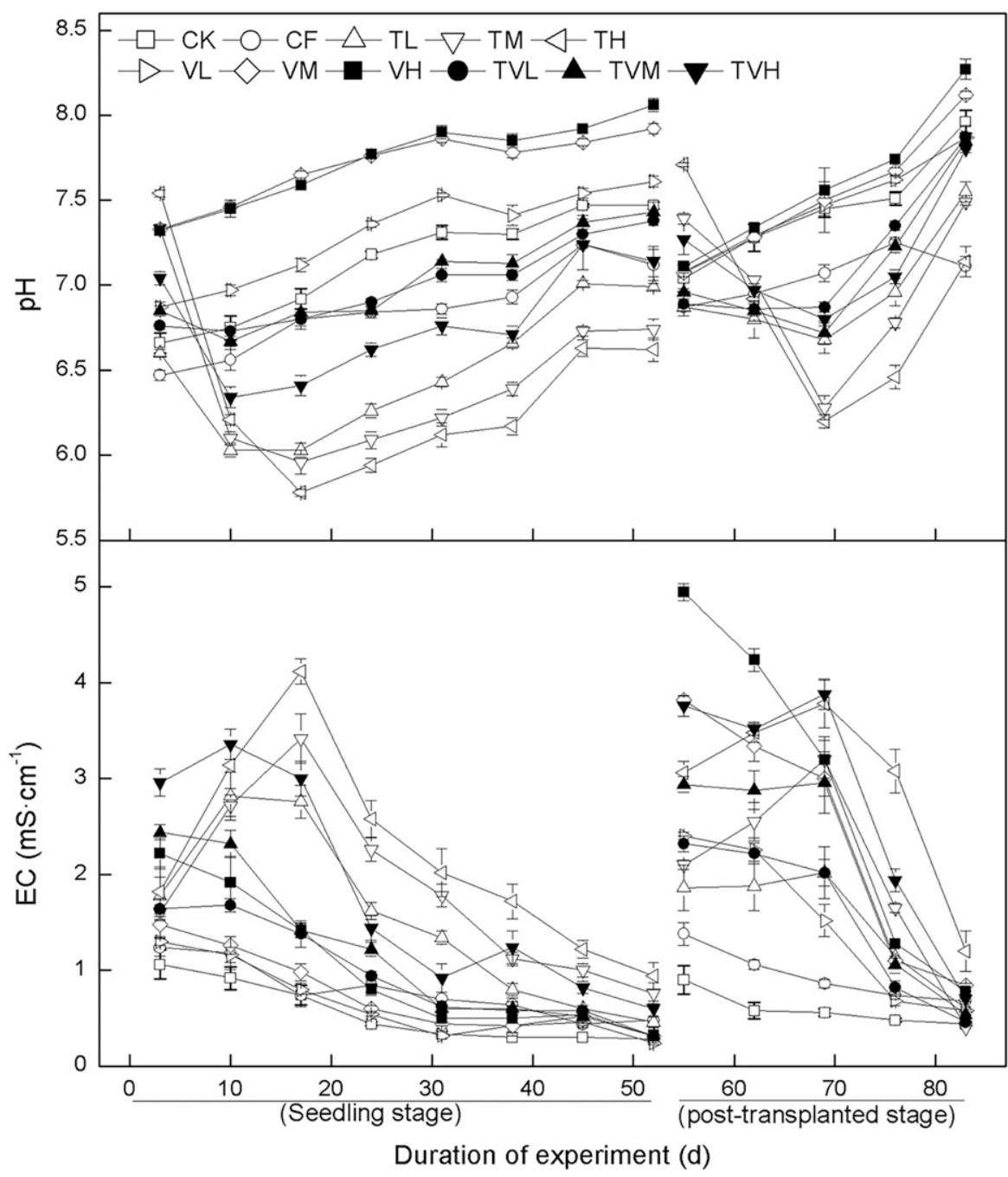

Fig. 1. Effect of organic fertilizer source and rate on substrate leachate $\mathrm{pH}$ and electrical conductivity (EC). The $\mathrm{pH}$ and $\mathrm{EC}$ values were measured by the pourthrough method weekly after organic fertilizer treatments $(n=4): C K=$ control (no fertilization), CF = fertigation using $150 \mathrm{mg} \cdot \mathrm{L}^{-1}$ nitrogen $(\mathrm{N})$ from conventional liquid fertilizer 21N-2.2P-16.6K (Jack's Professional LX 21-5-20 All Purpose Water-Soluble Fertilizer; J.R. Peters, Allentown, PA). TL, TM, and TH represent the applications of $0.32,0.64$, and $0.96 \mathrm{lb} / \mathrm{yard}^{3} \mathrm{~N}$ of turkey litterbased compost $8 \mathrm{~N}-1.8 \mathrm{P}-3.3 \mathrm{~K}$ (Sustane Natural Fertilizer, Cannon Falls, $\mathrm{MN}$ ) to substrate, respectively. VL, VM, and VH represent the application of $0.32,0.64$, and $0.96 \mathrm{lb} /$ yard $^{3} \mathrm{~N}$ of dairy manure vermicompost $3.4 \mathrm{~N}-1.5 \mathrm{P}-3.1 \mathrm{~K}$ (Worm Power, Avon, NY) to substrate, respectively. TVL, TVM, and TVH represent the applications of $0.32,0.64$, and $0.96 \mathrm{lb} / \operatorname{yard}^{3} \mathrm{~N}$ of the combination of aforementioned two organic fertilizers $(1: 1 \mathrm{~N}$ by weight $) ; 1 \mathrm{mg} \cdot \mathrm{L}^{-1}=1 \mathrm{ppm}, 1 \mathrm{lb} /$ $\operatorname{yard}^{3}=0.5933 \mathrm{~kg} \cdot \mathrm{m}^{-3}, 1 \mathrm{mS} \cdot \mathrm{cm}^{-1}=1 \mathrm{mmho} / \mathrm{cm}$.

\section{Results}

Substrate Leachate pH AND EC. Organic fertilizer source and rate affected the substrate leachate $\mathrm{pH}$ values (Fig. 1). For the TC treatments, substrate leachate $\mathrm{pH}$ decreased for the first $17 \mathrm{~d}$ after seeding and then increased; whereas for $\mathrm{VC}, \mathrm{pH}$ increased continuously over time from days 0 to 52. In general, substrate leachate $\mathrm{pH}$ for the TC treatment varied between 6.0 and 7.5. Substrate leachate $\mathrm{pH}$ for the VC treatment varied between 6.9 and 8.1. When the two organic fertilizers were combined, substrate leachate $\mathrm{pH}$ exhibited an initial decline in $\mathrm{pH}$, which then increased to day 52 . Overall, $\mathrm{pH}$ varied between 6.3 and 7.4. During the seedling or posttransplanted stages, substrate leachate $\mathrm{pH}$ values in the control treatment significantly increased over time. Meanwhile, CF application decreased substrate leachate $\mathrm{pH}$ compared with CK. In general, the changes of substrate leachate $\mathrm{pH}$ during the posttransplanted stage had similar trends with seedling stage. However, substrate leachate $\mathrm{pH}$ during the posttransplanted stage was somewhat higher compared with the seedling stage, which was probably because of the effects of a larger posttransplanted root zone substrate and larger plant size, which required greater volume of irrigation with moderatealkalinity water.

The EC differed greatly among fertilizer treatments (Fig. 1). During seedling or posttransplanted stages, both TC and VC treatments and their combinations resulted in increased substrate leachate EC values compared with the controls. In addition, substrate leachate EC increased with increasing $\mathrm{TC}, \mathrm{VC}$, and $\mathrm{TC} / \mathrm{VC}$ application. For TC, the EC increased for the first 2 weeks after addition, then declined over time; whereas for VC, the EC declined following addition, and for TC/VC combinations, $\mathrm{EC}$ was stable for $\approx 2$ weeks and then declined. During the experimental period, CF treatment resulted in increased substrate leachate EC compared with CK.

S U B S TRATE LEACHATE NUTRIENTS. In the seedling stage, substrate leachate nutrient concentrations were affected by organic fertilizer source and rate (Fig. 2). Data were not taken after transplant. For $\mathrm{Ca}$ and $\mathrm{NO}_{3}{ }^{-}-\mathrm{N}$, TC exhibited greater concentrations than the corresponding $\mathrm{VC}$ treatments as well as $\mathrm{CF}$ and $\mathrm{CK}$. For TC, $\mathrm{Ca}$, and $\mathrm{NO}_{3}{ }^{-} \mathrm{N}$ concentration in leachate increased to $17 \mathrm{~d}$ and then decreased. For VC treatments, there was very low $\mathrm{Ca}$ and $\mathrm{NO}_{3}{ }^{-} \mathrm{N}$ in leachate by $24 \mathrm{~d}$, suggesting most had been taken up by the plant or leached. Substrate leachate $\mathrm{Ca} / \mathrm{NO}_{3}{ }^{-}-\mathrm{N}$ concentrations for TC/VC treatments exhibited a pattern in-between the TC and $\mathrm{VC}$ treatments with relatively stable/ slightly declining concentration to $17 \mathrm{~d}$, a fairly dramatic decline between 17 and $24 \mathrm{~d}$, and a more gradual decline thereafter.

Organic fertilizer application (and increasing rate of application) increased substrate leachate K concentration compared with CK and CF. For TC and TC/VC combination, $\mathrm{K}$ concentration in leachate was stable for the first 17 $\mathrm{d}$ after addition and then declined. For $\mathrm{VC}, \mathrm{K}$ concentration in leachate was 

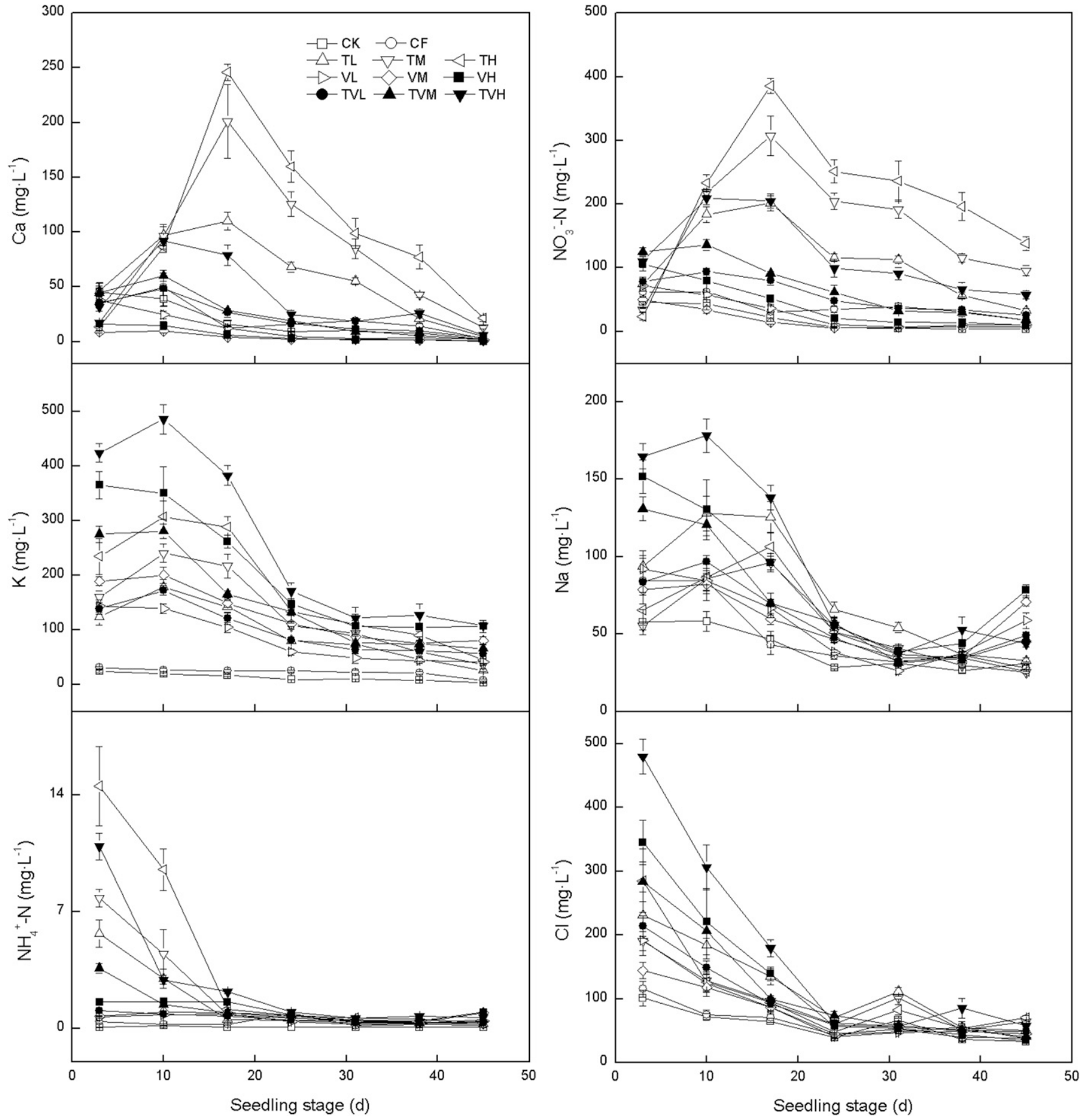

Fig. 2. Effect of organic fertilizer source and rate on the concentrations of calcium $(\mathrm{Ca})$, nitrate-nitrogen $\left(\mathrm{NO}{ }_{3}{ }^{-}-\mathrm{N}\right)$, potassium $(\mathrm{K})$, sodium $(\mathrm{Na})$, ammonium-nitrogen $\left(\mathrm{NH}_{4}{ }^{+}-\mathrm{N}\right)$, and chloride $(\mathrm{Cl})$ in substrate leachate. Data were determined weekly using a multi-ion meter (CG001; CleanGrow, Vacaville, CA) by pour-through method. CK = control (no fertilization), CF = fertigation using $150 \mathrm{mg} \cdot \mathrm{L}^{-1}$ nitrogen $(\mathrm{N})$ from conventional liquid fertilizer $21 \mathrm{~N}-2.2 \mathrm{P}-16.6 \mathrm{~K}$ (Jack's Professional LX 215-20 All Purpose Water-Soluble Fertilizer; J.R. Peters, Allentown, PA). TL, TM, and TH represent the applications of 0.32, 0.64 , and $0.96 \mathrm{lb} /$ yard $^{3} \mathrm{~N}$ of turkey litter-based compost $8 \mathrm{~N}-1.8 \mathrm{P}-3.3 \mathrm{~K}$ (Sustane Natural Fertilizer, Cannon Falls, MN) to substrate, respectively. VL, VM, and VH represent the applications of $0.32,0.64$, and $0.96 \mathrm{lb} / \mathrm{yard}^{3} \mathrm{~N}$ of dairy manure vermicompost 3.4N-1.5P-3.1K (Worm Power, Avon, NY) to substrate, respectively. TVL, TVM, and TVH represent the applications of $0.32,0.64$, and $0.96 \mathrm{lb} / \mathrm{yard}^{3} \mathrm{~N}$ of the combination of aforementioned two organic fertilizers (1:1 $\mathrm{N}$ by weight). The vertical bars represent the standard errors $(\mathrm{n}=4) ; 1 \mathrm{lb} / \mathrm{yard}^{3}=0.5933 \mathrm{~kg} \cdot \mathrm{m}^{-3}, 1 \mathrm{mg} \cdot \mathrm{L}^{-1}=1 \mathrm{ppm}$.

stable for the first $10 \mathrm{~d}$ following addition and then declined. Similar trends for $\mathrm{Na}$ concentration in leachate were observed with $\mathrm{K}$
The $\mathrm{NH}_{4}{ }^{+} \mathrm{N}$ concentration in leachate of TC was quite high compared with VC, CK, or CF. For all organic fertilizer treatments, $\mathrm{NH}_{4}{ }^{+}-\mathrm{N}$ concentration in leachate decreased for the first $24 \mathrm{~d}$ following application and was minimal thereafter. Similar trends for $\mathrm{Cl}$ concentration in leachate were 
observed with $\mathrm{NH}_{4}{ }^{+}-\mathrm{N}$. The low substrate leachate concentration suggested that most of the $\mathrm{Na}, \mathrm{NH}_{4}{ }^{+} \mathrm{N}$, and $\mathrm{Cl}$ was no longer leached by $24 \mathrm{~d}$.

SEED GERMINATION AND SEEDLING GROWTH. Cucumber seed germination under two organic fertilizer treatments was more than $80 \%$ (Table 1); however, for TC, seedling survival rate ranged from $44 \%$ to $60 \%$. In this experiment, it was observed that the treatments containing TC fertilizers exhibited occurrence of root rot of seedlings. The two organic fertilizer treatments significantly increased seedling height and leaf number compared with CK. Cucumber seedling height and leaf number under the two organic fertilizer treatments did not differ with $\mathrm{CF}$. The TC or TC/VC combinations increased seedling SPAD readings compared with the controls; however, VC treatment did not affect seedling SPAD readings compared with the controls.

Transplant growth. The growth of cucumber transplants was affected by organic fertilizer sources and rate (Table 2 ). The stem length, leaf number, DW, RI, and SPAD readings increased with increasing TC and VC fertilizer applications. Compared with $\mathrm{CK}, \mathrm{TC} / \mathrm{VC}$ combinations increased the growth of cucumber transplants. The stem length, leaf number, $\mathrm{DW}, \mathrm{RI}$, and SPAD readings under CF were $4.1,2.4,14.5,2.7$, and 1.8 times that of CK. In general, the growth of cucumber transplants in $12 \mathrm{lb} /$ yard $^{3}$ of TC, $28.32 \mathrm{lb} /$ yard $^{3}$ of VC, and TC/ $\mathrm{VC}$ combinations was the same or close to $\mathrm{CF}$, which indicated that these organic fertilizers or their combinations were suitable for the cultivation of cucumber transplants. The RI of TC at the high level or medium and high level of the TC/VC blend was greater than control plants.

\section{Discussion and conclusions}

Substrate $\mathrm{pH}$ is an important chemical property that strongly influences nutrient availability in substrates (Ao et al., 2008; Li and

Table 1. Effect of organic fertilizer sources and rate on cucumber seed germination rate, seedling survival rate, and seedling related indices.

\begin{tabular}{|c|c|c|c|c|c|}
\hline Treatment $^{\mathrm{z}}$ & Germination rate $(\%)$ & Seedling survival rate (\%) & Seedling ht $(\mathrm{cm})^{\mathrm{y}}$ & Leaves (no./plant) & SPAD $^{x}$ \\
\hline $\mathrm{CK}$ & 91 & 100 & $17.1 c^{w}$ & $2.6 \mathrm{~d}$ & $33.1 \mathrm{def}$ \\
\hline $\mathrm{CF}$ & 100 & 100 & $20.9 \mathrm{a}$ & $4.6 \mathrm{a}$ & $35.0 \mathrm{cde}$ \\
\hline $\mathrm{TL}$ & 91 & 50 & $18.0 \mathrm{bc}$ & $3.2 \mathrm{~cd}$ & 35.9 bcde \\
\hline $\mathrm{TM}$ & 82 & 44 & $19.6 \mathrm{ab}$ & $4.0 \mathrm{abc}$ & $41.8 \mathrm{a}$ \\
\hline $\mathrm{TH}$ & 91 & 60 & $19.7 \mathrm{ab}$ & $4.0 \mathrm{abc}$ & $36.8 \mathrm{bcd}$ \\
\hline VL & 82 & 100 & $20.8 \mathrm{a}$ & $3.8 \mathrm{abc}$ & $32.7 \mathrm{ef}$ \\
\hline TVL & 82 & 67 & $20.0 \mathrm{ab}$ & $4.2 \mathrm{ab}$ & 34.2 cde \\
\hline TVM & 82 & 100 & $19.9 \mathrm{ab}$ & $3.6 \mathrm{bc}$ & $39.0 \mathrm{ab}$ \\
\hline TVH & 100 & 91 & $18.6 \mathrm{bc}$ & $3.8 \mathrm{abc}$ & $37.6 \mathrm{bc}$ \\
\hline
\end{tabular}

${ }^{\mathrm{z}} \mathrm{CK}=$ control (no fertilization); CF = fertigation using $150 \mathrm{mg} \cdot \mathrm{L}^{-1}$ nitrogen (N) from conventional liquid fertilizer 21N-2.2P-16.6K (Jack's Professional LX 21-5-20 All Purpose Water-Soluble Fertilizer; J.R. Peters, Allentown, PA). TL, TM, and TH represent the applications of $0.32,0.64$, and $0.96 \mathrm{lb} /$ yard ${ }^{3} \mathrm{~N}$ of turkey litter-based compost $8 \mathrm{~N}-1.8 \mathrm{P}-3.3 \mathrm{~K}$ (Suståne Natural Fertilizer, Cannon Falls, MN) to substrate, respectively. VL, VM, and VH represent the applications of $0.32,0.64$, and $0.96 \mathrm{lb} /$ yard ${ }^{3} \mathrm{~N}$ of dairy manure vermicompost 3.4N-1.5P-3.1K (Worm Power, Avon, NY) to substrate, respectively. TVL, TVM, and TVH represent the applications of $0.32,0.64$, and 0.96 $\mathrm{lb} / \operatorname{yard}^{3} \mathrm{~N}$ of the combination of aforementioned two organic fertilizers $(1: 1 \mathrm{~N}$ by weight $) ; 1 \mathrm{mg} \cdot \mathrm{L}^{-1}=1 \mathrm{ppm}, 1 \mathrm{lb} / \mathrm{yard} \mathrm{d}^{3}=0.5933 \mathrm{~kg} \cdot \mathrm{m}^{-3}$.

${ }^{\mathrm{y}} 1 \mathrm{~cm}=2.54$ inch.

${ }^{\mathrm{x}} \mathrm{SPAD}=$ leaf greenness, which was quantified for all plants using a nondestructive dual-wavelength chlorophyll meter (Minolta SPAD-502 chlorophyll meter; Spectrum Technologies, Plainfield, IL) and taking the average reading of three recent mature leaves per plant.

${ }^{w}$ Means $(n=4)$ in each column followed by the same letters are not significantly different according to least significant difference test at $P<0.05$.

Table 2. Effects of organic fertilizer sources and rate on the growth of cucumber transplants.

\begin{tabular}{|c|c|c|c|c|c|}
\hline Treatment $^{\mathrm{z}}$ & Stem length $(\mathrm{cm})^{\mathrm{y}}$ & Leaves (no./plant) & Dry wt (g/plant $)^{y}$ & $\mathrm{RI}(0-5 \text { scale })^{\mathrm{x}}$ & SPAD $^{\mathrm{x}}$ \\
\hline $\mathrm{CK}$ & $16.4 \mathrm{e}^{\mathrm{w}}$ & $4.8 \mathrm{~d}$ & $0.78 \mathrm{f}$ & $1.3 \mathrm{~g}$ & $20.7 \mathrm{e}$ \\
\hline $\mathrm{CF}$ & $66.6 \mathrm{a}$ & $11.6 \mathrm{a}$ & $11.34 \mathrm{a}$ & 3.5 cde & $36.9 \mathrm{a}$ \\
\hline $\mathrm{TL}$ & $39.2 \mathrm{~d}$ & $8.4 c$ & $4.15 \mathrm{e}$ & $2.4 \mathrm{f}$ & $31.8 \mathrm{c}$ \\
\hline $\mathrm{TM}$ & $53.0 \mathrm{bc}$ & $9.6 \mathrm{bc}$ & $8.72 \mathrm{~cd}$ & $3.3 \mathrm{de}$ & 33.9 bc \\
\hline $\mathrm{TH}$ & $67.4 \mathrm{a}$ & $11.8 \mathrm{a}$ & $10.80 \mathrm{ab}$ & $4.4 \mathrm{a}$ & $34.9 \mathrm{ab}$ \\
\hline VL & $46.6 \mathrm{~cd}$ & $9.6 \mathrm{bc}$ & $5.26 \mathrm{e}$ & $3.1 \mathrm{e}$ & $26.7 \mathrm{~d}$ \\
\hline TVL & $62.4 \mathrm{ab}$ & $11.0 \mathrm{ab}$ & $8.12 \mathrm{~d}$ & $3.7 \mathrm{bcd}$ & $32.4 \mathrm{bc}$ \\
\hline TVM & $64.8 \mathrm{a}$ & $12.0 \mathrm{a}$ & $10.81 \mathrm{ab}$ & $4.1 \mathrm{ab}$ & $32.5 \mathrm{bc}$ \\
\hline TVH & $62.2 \mathrm{ab}$ & $12.0 \mathrm{a}$ & $10.17 \mathrm{abc}$ & $4.0 \mathrm{abc}$ & $34.7 \mathrm{ab}$ \\
\hline
\end{tabular}

${ }^{\mathrm{z}} \mathrm{CK}=$ control (no fertilization); $\mathrm{CF}=$ fertigation using $150 \mathrm{mg} \cdot \mathrm{L}^{-1}$ nitrogen (N) from conventional liquid fertilizer 21N-2.2P-16.6K (Jack's Professional LX 21-5-20 All Purpose Water-Soluble Fertilizer; J.R. Peters, Allentown, PA). TL, TM, and TH represent the applications of $0.32,0.64$, and $0.96 \mathrm{lb} /$ yard ${ }^{3} \mathrm{~N}$ of turkey litter-based compost $8 \mathrm{~N}-1.8 \mathrm{P}-3.3 \mathrm{~K}$ (Suståne Natural Fertilizer, Cannon Falls, MN) to substrate, respectively. VL, VM, and VH represent the applications of $0.32,0.64$, and $0.96 \mathrm{lb} /$ yard ${ }^{3} \mathrm{~N}$ of dairy manure vermicompost 3.4N-1.5P-3.1K (Worm Power, Avon, NY) to substrate, respectively. TVL, TVM, and TVH represent the applications of $0.32,0.64$, and 0.96 $\mathrm{lb} / \mathrm{yard}^{3} \mathrm{~N}$ of the combination of aforementioned two organic fertilizers $(1: 1 \mathrm{~N}$ by weight $) ; 1 \mathrm{mg} \cdot \mathrm{L}^{-1}=1 \mathrm{ppm}, 1 \mathrm{lb} / \mathrm{yard}{ }^{3}=0.5933 \mathrm{~kg} \cdot \mathrm{m}^{-3}$.

${ }^{\mathrm{y}} 1 \mathrm{~cm}=2.54$ inch, $1 \mathrm{~g}=0.0353 \mathrm{oz}$.

${ }^{\mathrm{x}}$ Root index, where $0=$ no visible roots at the substrate surfaces and $5=$ visible roots were matted on the surface of the substrate. SPAD $=$ leaf greenness measured using a chlorophyll meter (Minolta SPAD-502 chlorophyll meter, Spectrum Technologies, Plainfield, IL).

${ }^{\mathrm{w}}$ Means $(\mathrm{n}=4)$ in each column followed by the same letters are not significantly different according to least significant difference test at $P<0.05$ 
Mattson, 2016; Yeager et al., 1983). Substrate EC values reflect changes in nutrient and non-nutrient ion release (Li et al., 2013). For cucumber, optimal $\mathrm{pH}$ and $\mathrm{EC}$ values are in the intervals 5.5 to 6.2 and 2.0 to 3.0 $\mathrm{mS} \cdot \mathrm{cm}^{-1}$, respectively (Rur, 2016; Valenzuela et al., 1994). Bi et al. (2010) reported that organic fertilizers may contribute to high substrate $\mathrm{pH}$ and EC. Substrate $\mathrm{pH}$ increased with addition of the amendment based on alfalfa (Medicago sativa) but remained within the acceptable range of 5.5 to 7.0 (Nair et al., 2011). In this experiment, the TC application decreased substrate leachate $\mathrm{pH}$ values, whereas VC increased $\mathrm{pH}$ values. Substrate leachate $\mathrm{pH}$ values of the control treatments significantly increased over time during the seedling stage and after transplant, which is likely because the tap water used in this study had moderate alkalinity [120 $\mathrm{mg} \cdot \mathrm{L}^{-1}$ calcium carbonate $\left.\left(\mathrm{CaCO}_{3}\right)\right]$, similar to findings by Camberato et al. (2013). Compared with $\mathrm{CK}, \mathrm{CF}$ application resulted in decreased substrate leachate $\mathrm{pH}$, which is because the water-soluble fertilizer used is moderately acidic (potential acidity $390 \mathrm{lb} /$ ton $\mathrm{CaCO}_{3}$ equivalent). Substrate leachate EC differed greatly among fertilizer treatments over time. The TC treatments led to increased substrate leachate EC values for approximately the first 2 weeks and then decreased significantly over time. Substrate leachate EC for VC applications decreased over time beginning at experiment initiation; however, substrate leachate $\mathrm{EC}$ for TC/VC combinations remained stable for $17 \mathrm{~d}$, due to the combined effects of the two components, and then decreased thereafter. Substrate leachate EC differed slightly between the seedling stage and posttransplanted stage, especially under VC treatments, which was possibly due to substrate volumes, plant water/nutrient use and the irrigation amounts. In addition, cucumber flowers and fruit are physically and hormonally significant organs in nutrient and water movement. At the end of the posttransplanted stage, cucumber flowers and fruit were observed in fertilizer treatments.

In organic greenhouse production, fertilizer sources are often assessed based on the timing of $\mathrm{N}$ release relative to crop demand because $\mathrm{N}$ is often the most limiting factor among all the nutrients required for plant growth and development (Treadwell et al., 2007). The study of Williams and Nelson (1992) indicated that seven organic sources, including bacteria (Brevibacterium lactofermentum) in a nonviable state, a mixture of bacteria (Bacillus licheniformis and Bacillus subtilis) and fungi (Aspergillus niger) in a nonviable state, an activated microbial sludge from wastewater treatment, sludge from a poultry manure methane generator, unsteamed bonemeal, aged pine (Pinus sp.) needles, and poultry feathers released $\mathrm{N}$ most rapidly during the first 2 weeks, followed by a decline, which ended at 6 to 7 weeks. In this experiment, substrate leachate $\mathrm{NO}_{3}{ }^{-} \mathrm{N}$ concentrations for VC treatments decreased over time. However, substrate leachate Ca concentration for VC treatments decreased over time to $24 \mathrm{~d}$ and then did not further change. The $\mathrm{NO}_{3}{ }^{-}-\mathrm{N}$ and $\mathrm{Ca}$ concentrations in substrate leachate for TC treatments increased over time to $17 \mathrm{~d}$ and then decreased. The changes of substrate leachate $\mathrm{NO}_{3}{ }^{-} \mathrm{N}$ and $\mathrm{Ca}$ concentrations for $\mathrm{TC} / \mathrm{VC}$ combinations had similar trend with TC treatment. Results of this study showed that strong linear relations were found between EC and $\mathrm{Ca}\left(R^{2}=0.69, \mathrm{n}=77, P<\right.$ $0.0001)$, and between EC and $\mathrm{NO}_{3}^{-}{ }^{-\mathrm{N}}\left(R^{2}=0.81, \mathrm{n}=77, \mathrm{P}<\right.$ 0.0001 ) (data not shown). This linear relationship indicates that under our experimental conditions, substrate leachate $\mathrm{NO}_{3}{ }^{-} \mathrm{N}$ and $\mathrm{Ca}$ concentrations could be estimated by measuring substrate leachate EC values. Such relations are useful for growers who wish to estimate substrate $\mathrm{NO}_{3}^{-}-\mathrm{N}$ and $\mathrm{Ca}$ concentrations from EC readings when using the pour-through method.

Different organic fertilizers had differently affected substrate leachate $\mathrm{K}$ and $\mathrm{Na}$ concentrations. Substrate leachate $\mathrm{K}$ and $\mathrm{Na}$ concentrations for $\mathrm{TC}$ and TC/VC blend treatments increased over time to $17 \mathrm{~d}$ and then decreased. For VC, $\mathrm{K}$ and $\mathrm{Na}$ did not change over time to $10 \mathrm{~d}$ and then declined. Meanwhile, TC/VC combinations resulted in increased $\mathrm{K}$ concentrations compared with TC or VC treatment, indicating that there was a potential synergistic impact of TC/ $\mathrm{VC}$ combinations on $\mathrm{K}$ and $\mathrm{Na}$ release. In addition, substrate leachate $\mathrm{NH}_{4}{ }^{+}-\mathrm{N}$ and $\mathrm{Cl}$ concentrations were differently affected by different organic fertilizers. Hawkins (2010) reported $\mathrm{NH}_{4}{ }^{+} \mathrm{N}$ varied for 4.8 (composted yard waste) to 19.25 $\mathrm{mg} \cdot \mathrm{L}^{-1}$ (shellfish-based compost). In this experiment, $\mathrm{NH}_{4}{ }^{+}-\mathrm{N}$ concentrations for TC and TC/VC blend were higher than VC treatments.

Seed germination and plant growth was affected by organic fertilizer source and rates. Nair et al. (2011) reported that an alfalfa-based substrate-incorporated fertilizer was suitable for producing commercially acceptable 6-week-old tomato transplants if a 1 - to 3 -week incubation period was used before seeding. Germination percentages were less than $50 \%$ in amended substrate that was either not incubated or incubated for 4 weeks. Germination was greater than $75 \%$ if amended substrates were incubated for 1,2 , or 3 weeks. Seeds grown in peatcompost without any amendments had the highest germination rates; however, severe nutrient deficiency suppressed seedling growth. Relative to growth in substrate with no amendments, plants growing in the amended substrate had increased stem diameter, height, leaf chlorophyll content, and plant DW, provided the amended substrate was incubated for at least 1 week. Mattson (2014) reported that performance of bedding plants grown with substrateincorporated organic fertilizers compared with $\mathrm{CF}$ and controlled-release fertilizer (CRF). Liquid fertilized plants were the largest in all cases; however, for coleus (Plectranthus scutellarioides), fibrous begonia (Begonia fibrosa), and pansy (Viola tricolor), the organic fertilized plants were, in general, of similar size to CRF plants and considered commercially marketable. Bi et al. (2010) evaluated the growth and flowering responses of greenhouse-grown 'Janie Deep Orange' French marigold (Tagetes patula) with two noncomposted broiler chicken litter-based organic fertilizers, $4 \mathrm{~N}-0.9 \mathrm{P}-1.7 \mathrm{~K}$ (applied at $1 \%$ to $8 \%$ by volume) and $3 \mathrm{~N}-1.3 \mathrm{P}-$ $2.5 \mathrm{~K}$ (applied at $1.3 \%$ to $8.0 \%$ by volume). Low to intermediate rates of $4 \mathrm{~N}-0.9 \mathrm{P}-1.7 \mathrm{~K}$ and $3 \mathrm{~N}-1.3 \mathrm{P}-$ $2.5 \mathrm{~K}$ fertilizers in general produced the highest plant growth index, shoot DW, number of flowers per plant, total flower DW, and root rating. 
Plants grown at high rates of $4 \mathrm{~N}-$ $0.9 \mathrm{P}-1.7 \mathrm{~K}$ and $3 \mathrm{~N}-1.3 \mathrm{P}-2.5 \mathrm{~K}$ fertilizers showed symptoms associated with excessive fertilization. In addition, Eo and Park (2013) reported that the application of manure composts may accelerate root rot disease by promoting pathogenic fungi. In practice, growers need to be cautious with organic fertilizer application rates. Because different crops may respond differently to these natural fertilizers, it is important for growers to test any new fertilizers before incorporating them into their production practices (Bi et al., 2010). In our experiment, it was observed that the treatments containing TC fertilizers resulted in the occurrence of root rot of seedlings. This suggests care may need to be taken with fertilization application rate, especially for sensitive seedlings. Cucumber seedling growth indices for high rate of VC treatment increased compared with CK, but did not differ with CF. The stem length, leaf number, DW, $\mathrm{RI}$, and SPAD of cucumber transplants increased with increasing TC and $\mathrm{VC}$ applications, respectively. The TC/VC combinations did not affect the growth of cucumber transplants compared with CF. The results of this study indicated that the high rate of VC or the medium rate of VC combined with TC can be substituted for $\mathrm{CF}$ for the cultivation of cucumber seedlings. Based on DW, the high rate of TC or the medium rate of TC combined with VC fertilizers was a suitable replacement for $\mathrm{CF}$ for the cultivation of cucumber transplants.

\section{Literature cited}

Alsadon, A., I. Al-Helal, A. Ibrahim, A. Abdel-Ghany, S. Al-Zaharani, and T. Ashour. 2016. The effects of plastic greenhouse covering on cucumber (Cucumis sativus L.) growth. Ecol. Eng. 87:305-312.

Ao, Y., M. Sun, and Y. Li. 2008. Effect of organic substrates on available elemental contents in nutrient solution. Bioresour. Technol. 99:5006-5010.

Arancon, N.Q., C.A. Edwards, R.M. Atiyeh, and M.J. Metzger. 2004. Effects of vermicomposts produced from food waste on the growth and yields of greenhouse peppers. Bioresour. Technol. 93:139-144.

Arancon, N.Q., C.A. Edwards, and P. Bierman. 2006. Influences of vermicomposts on field strawberries: Part 2. Effects on soil microbiological and chemical properties. Bioresour. Technol. 97:831-840.
Atiyeh, R.M., S. Subler, C.A. Edwards, G. Bachman, J.D. Metzger, and W. Shuster. 2000. Effects of vermicomposts and composts on plant growth in horticultural container media and soil. Pedobiologia 44:579-590.

Baca, M.T., F. Fornasier, and M. de Nobili. 1992. Mineralization and humification pathways in two composting processes applied to cotton wastes. J. Ferment. Bioeng. 74:179-184.

Bi, G., W.B. Evans, and G.B. Fain. 2009. Use of pulp mill ash as a substrate component for greenhouse production of marigold. HortScience 44:183-187.

Bi, G., W.B. Evans, J.M. Spiers, and A.L. Witcher. 2010. Effects of organic and inorganic fertilizers on Marigold growth and flowering. HortScience 45:1373-1377.

Brace, S.A. 2017. Vermicompost application as a fertilizer source and substrate amendment for seedlings and transplants: Practical application and microbial activity analysis. Cornell Univ., Ithaca, NY, PhD Diss.

Burnett, S.E., N.S. Mattson, and K.A. Williams. 2016. Substrates and fertilizers for organic container production of herbs vegetables, and herbaceous ornamental plants grown in greenhouses in the United States. Scientia Hort. 208:111-119.

Camberato, D.M., J.J. Camberato, and R.G. Lopez. 2013. Comparing the adequacy of controlled-release and watersoluble fertilizers for bedding plant production. HortScience 48:556-562.

Eo, J. and K.-C. Park. 2013. Effects of manure composts on soil biota and rootrot disease incidence of ginseng (Panax ginseng). Appl. Soil Ecol. 71:58-64.

Food and Agriculture Organization of the United Nations. 2019. All FAOSTAT data. 2 Apr. 2019. <http://www.fao. org/faostat/en/\#home>.

Gaskell, M. and R. Smith. 2007. Nitrogen sources for organic vegetable crops. HortTechnology 17:431-441.

Hartz, T.K. and P.R. Johnstone. 2006. Nitrogen availability from high-nitrogencontaining organic fertilizers. HortTechnology 16:39-42.

Hawkins, M.R. 2010. Consumer interest and compost substrate management of organic and sustainable plants. Univ. Maine, Orono, MS Thesis.

Li, Y. and N.S. Mattson. 2016. Effect of different commercial substrates on growth of petunia transplants. HortTechnology 26:507-513.

Li, Y., J. Qin, N.S. Mattson, and Y. Ao. 2013. Effect of potassium application on celery growth and cation uptake under dif- ferent calcium and magnesium levels in substrate culture. Scientia Hort. 158:33-38.

Mattson, N.S. 2014. Comparing substrate fertilizer amendments for spring bedding plants. Greenhouse Grower 32(13):48-54.

Meng, F., Y. Qiao, W. Wu, P. Smith, and S. Scott. 2017. Environmental impacts and production performances of organic agriculture in China: A monetary valuation. J. Environ. Mgt. 188:49-57.

Nair, A., M. Ngouajio, and J. Biernbaum. 2011. Alfalfa-based organic amendment in peat-compost growing medium for organic tomato transplant production. HortScience 46:253-259.

Olczyk, T., Y. Qian, K.W. Migliaccio, Y.C. Li, G.J. Hochmuth, R.C. Hochmuth, E.H. Simonne, D.D. Treadwell, L.S. Osborne, and R.K. Sprenkel. 2007. Nutrient management for greenhouse production of container-grown organic herbs. Proc. Florida State Hort. Soc. 120:178-180.

Rur, M. 2016. Developing IPM tools for greenhouse cucumber production in Sweden - a participatory action research approach. 7 Apr. 2019. <https://pub.epsilon.slu.se/ 13668/1/Rur_M_160916.pdfs.

Treadwell, D.D., G.J. Hochmuth, R.C. Hochmuth, E.H. Simonne, L.L. Davis, W.L. Laughlin, Y. Li, T. Olczyk, R.K. Sprenkel, and L.S. Osborne. 2007. Nutrient management in organic greenhouse herb production: Where are we now? HortTechnology 17:461-466.

Valenzuela, H.R., R.T. Hamasaki, and S.K. Fukuda. 1994. Field cucumber production guidelines for Hawaii. 7 Apr. 2019. <https://www.ctahr.hawaii.edu/ oc/freepubs/pdf/RES-151.pdf $>$.

Williams, K.A. and P.V. Nelson. 1992. Low, controlled nutrient availability provided by organic waste materials for chrysanthemum. J. Amer. Soc. Hort. Sci. 117:422-429.

Wright, R.D. 1986. The pour-through nutrient extraction procedure. HortScience 21:227-229.

Yang, L., F. Zhao, Q. Chang, T. Li, and F. Li. 2015. Effects of vermicomposts on tomato yield and quality and soil fertility in greenhouse under different soil water regimes. Agr. Water Mgt. 160:98-105.

Yeager, T.H., R.D. Wright, and S.J. Donohue. 1983. Comparison of pourthrough and saturated pine bark extract $\mathrm{N}, \mathrm{P}, \mathrm{K}$, and $\mathrm{pH}$ levels. J. Amer. Soc. Hort. Sci. 108:112-114.

Zhao, H., J. Luo, Y. Shan, A. Wang, P. Liu, and K. Feng. 2010. Effects of vermicompost organic-inorganic mixed fertilizer on yield and quality components of cucumber cultivated in greenhouse. Plant Nutr. Fert. Sci. 16:1288-1293. 